\title{
Beata Michalska
}

Uniwersytet im. Adama Mickiewicza

\section{"Pigułka szczęścia", czyli o kreacji świata na internetowych stronach gabinetów stomatologicznych (leksyka wartościująca)}

Internet to medium o najszybciej zwiększającym się zasięgu, zdecydowanie skracające drogę do odbiorcy, stwarzające poczucie bliskości z użytkownikiem; dzięki temu serwis internetowy może wpływać zarówno na przekonania, jak i uczucia odbiorców. Poza dostarczaniem informacji o firmie, misji, strukturze organizacyjnej, realizowanych działaniach, ofercie czy cechach usługi lub produktu (funkcja informacyjna), promocją i reklamą (funkcja perswazyjna), budowaniem marki i wizerunku (funkcja kreatywna - tworzenie wizji świata1), firmowa strona internetowa ma również na celu dostarczanie pozytywnych doznań. Przekazywane treści są często pełne naiwnego patosu i obracają się $w$ kręgu szczęśliwości ${ }^{2}$, propagując tak zwane „modne życie”. Uogólniając możemy stwierdzić, że funkcją tekstów reklamowych jest kreowanie potrzeb, głównie przez uświadamianie braku, rozbudzanie chęci posiadania oraz wywieranie wpływu na wybór, jakiego dokonuje konsument (tutaj pacjent), przy czym we wszystkich tekstach o funkcjach perswazyjnych mamy do czynienia z kreowaniem świata i kształtowaniem pozytywnego wyobrażenia o nim.

1 Wykorzystywana tu terminologia w zakresie funkcji (intencji) wypowiedzi pochodzi z artykułu Renaty Grzegorczykowej [Grzegorczykowa 1991: 11-28].

2 O braku troski o realizm $w$ reklamie pisze Ryszard Tokarski [Tokarski 1995: 34]. 
Badanie kilkuset internetowych stron gabinetów stomatologicznych prowadzi do wniosku, że wartości uobecniane na nich dzięki właściwie dobranej leksyce odnoszą się do ogólnoreklamowych ${ }^{3}$ kategorii psychospołecznych wynikających z potrzeby budowania wizerunku. Autorzy tych tekstów posługują się obszernym zasobem językowych określeń wartościujących, które odnoszą się do wspólnej podstawy aksjologicznej. Z lingwistycznego i pragmatycznego punktu widzenia przekaz reklamowy należy do tekstów nakłaniających - na funkcję perswazyjną składają się w nim trzy mechanizmy: emocjonalizacja odbioru, wspólnota świata i języka oraz łatwa orientacja aksjologiczna.

Przedmiotem mojego zainteresowania będzie więc komunikowanie wartości odnoszących się do najważniejszych aspektów życia: interakcji społecznych, pojęcia sensu życia, szczęścia i satysfakcji życiowej oraz ról społecznych. Badania te wpisują się w szerszy zakres prowadzonych przeze mnie studiów nad leksyką w branżowej komunikacji elektronicznej. Dodam, że $w$ artykule pomijam zupełnie szatę graficzną oraz nawigację badanych stron, skupiając się jedynie na werbalnej ich zawartości; sama retoryka ${ }^{4}$ chyba już nie wystarcza do opisu złożonych zjawisk wizualno-werbalnych współczesnej reklamy. Zdaję sobie sprawę z tego, że izolacja analiz od pozawerbalnego kontekstu stanowi znaczne ograniczenie problematyki, ale całościowe traktowanie tekstu kultury, jakim jest przekaz reklamowy, wymagałoby wnikliwej współpracy językoznawców z badaczami z zakresu psychologii, filozofii, socjologii, marketingu i ekonomii, co przekracza ramy niniejszego artykułu.

W powszechnej opinii społecznej reklama tworzy obraz idealnego świata, odwołując się do wartości intersubiektywnie uważanych za pozytywne (sukces, mądrość, piękno, zdrowie), a owa

3 Zupełnie pomijam tutaj ograniczenia, jakie $w$ zakresie reklamy usług medycznych nakłada prawo na lekarzy będących właścicielami prywatnych gabinetów. Szerzej o tym piszę w artykule Lekarz szuka pacjenta. Leksyka wartościująca pozytywnie na internetowych stronach gabinetów stomatologicznych [w druku].

${ }_{4}$ P.H. Lewiński sugeruje, że do zainteresowań klasycznej retoryki, czyli triady: polityka, wymiar sprawiedliwości i religia doszedł nowy element - rynek. Zob. Lewiński 2000: 205. 
idealizacja zostaje podporządkowana celowi konsumpcyjnemu [Lewiński 2000: 205]. Ważną rolę $w$ tej idealizacji odgrywa język. On bowiem m.in. wytwarza wspólnotę myślenia i dekodowania, wpływając na nasze zachowania i subiektywny system wartości. Językowa kreatywność jako proces twórczy jest przeciwstawiana automatyzmowi (odtwórczości), oznacza też stwarzanie pewnych nowych stanów rzeczy ${ }^{5}$. Tematykę kreowania rzeczywistości w reklamie podejmowali już wcześniej przedstawiciele różnych nurtów intelektualnych, tradycji lingwistycznych, socjologicznych i filozoficznych.

W przekazach reklamowych zakłada się istnienie pewnego jednolitego porządku społecznego - do jego opisu używa się podobnych narzędzi sugerujących wartości, stałych kategorii, gotowych znaczeń, szablonów leksykalnych i składniowych. Wiedza ogólnospołeczna jest wiedzą podręczną (taken for granted), a każda reklama powiela utarte schematy i budowana jest na podstawie wspólnego doświadczenia. Aby problem wyjaśnić, należy zagłębić się $w$ zagadnienie rzeczywistości społecznej, rozumianej jako sposób funkcjonowania ludzi i rzeczy $w$ przestrzeni oraz zbiór wszystkich ich wzajemnych stosunków i zasad, na jakich się opierają ${ }^{6}$. Reklama wywiera ukierunkowany wpływ na decyzje człowieka, przedstawiane $w$ niej obrazy tworzą iluzję rzeczywistości. Werbalna warstwa przekazu reklamowego to język „haseł”, które działają na emocje odbiorców, apelując do ich słabości, a także podejmując próbę wytworzenia nowych potrzeb oraz wzbudzenia tęsknot. Jak już wspominałam, przekazy reklamowe opierają się na elementach zastanych $w$ kulturze, okazuje się jednak, że nie tylko - tworzą też nowe jakości, niejako nadbudowując

5 Renata Grzegorczykowa wymienia cztery główne obszary kreatywności językowej: 1. Kreatywność języka w modelu generatywnym Chomsky'ego, 2. Stwarzanie nowych stanów rzeczy przy performatywnym użyciu wyrażeń językowych, 3. Kreowanie zbitek pojęciowych wyrażanych przez słownictwo, 4. Stwarzanie światów przedstawionych w różnego typu tekstach, zwłaszzza w tekstach perswazyjnych [Grzegorczykowa 1995: 13].

6 Zob. Bogunia-Borowska 2004: 13 oraz Sawicka 2007: 277-288. 
świat znaczeń. Tym samym przekształcają rzeczywistość, czerpiąc z zasobu metaforycznych pojęć; a metafora odnajduje się tu idealnie, bo pozwala uwypuklić to, co pożądane. Zaskakujący, ale naukowo dowiedziony jest fakt, że ludzie reagują na rzeczywistość medialną tak, jak na rzeczywistość obiektywną. „Współczesne media współdziałają z dawnymi mózga$\mathrm{mi}$, ludzie nie zawsze są $w$ stanie pokonać wszechogarniające przekonanie, że prezentacje medialne są rzeczywistymi ludźmi i przedmiotami. Nie istnieje żaden przełącznik $w$ mózgu, dzięki któremu można by było rozróżnić świat rzeczywisty od medialnego" [Reeues, Nass 2010: 67]. Dlatego też współczesna reklama zdaje się przekraczać granicę sprzedaży, staje się czymś więcej - pewną propozycją myślenia o świecie.

Zdaniem Anety Dudy reklamowa ideologia „do realizacji swoich celów sięga po bardzo użyteczny środek mobilizujący pozaracjonalne sfery psychiki: po mit" [Duda 2010: 13], czyli społecznie ukształtowany obraz rzeczywistości, stale obecny w ludzkiej myśli i kulturze. Dzięki temu łatwo się do niego odwoływać - podkreśla dalej autorka. Stanowi on jeden z czynników konstytuujących współczesne społeczeństwo - jest społecznie ukształtowanym, uogólnionym obrazem rzeczywistości, opierającym się na zbiorze powszechnie akceptowanych twierdzeń, aksjomatów i założeń połączonych w pewien system dostosowany do zdolności percepcyjnych przeciętnego człowieka. Zasadniczą funkcją mitu jest ukazanie wzorcowych modeli działania - odzwierciedla on zatem już istniejące stosunki społeczne lub - częściej - jest wzorem, do którego człowiek dąży i którego osiągnięcie zapewni zaspokojenie jego wszystkich potrzeb. Rzeczywistość mitu jest jakościowo inna od rzeczywistości dnia codziennego. Mit to również środek koordynujący ludzkie postawy i zachowania, inspirujący konformizm, umożliwiający sterowanie wyobraźnią [Duda 2010: 4546]. Zjawisko reklamy jako całość jest formą mitu o człowieku i produkcie - za Rolandem Barthesem przyjmuje ostatecznie Aneta Duda [Duda 2010: 51]. 
Mimo że rzeczywistość obiektywna jest niezbędna do tego, by ludzie mogli się komunikować, przekazy reklamowe są doświadczane subiektywnie. Reklama dostarcza indywidualnych przeżyć, ale jest skarbnicą wiedzy potocznej i kontekstów kulturowych. „Każda dziedzina rzeczywistości społecznej staje się obiektywnie istotna, gdy zostaje odzwierciedlona przez subiektywne stany umysłu ludzkiego, czyli człowiek istnieje w świecie, w społeczeństwie na tyle, na ile doświadcza i dzieli jego obiekty oraz ich znaczenia z innymi ludźmi" [Bogunia-Borowska 2004; 18]. Proces takiej wymiany przypomina zamknięte koło - dyskurs reklamowy absorbuje informacje z rzeczywistości społecznej, zamyka je i oddaje $w$ zmienionej formie.

Nawiązując do pojęcia wspólnoty kulturowo-językowej, Grażyna Sawicka język reklamy nazywa wręcz stylem komunikacyjnym [Sawicka 2007: 278]. Wspólnota kulturowa rozumiana jest tu jako zbiorowość ludzi mówiących tym samym językiem i tworzących wspólną kulturę (poprzez język), w tym też konwencje, mogące występować na gruncie społecznym, kulturowym i językowym. Zasady regulujące styl reklamowy to konwencje społeczne (stereotyp związany ze społecznymi rolami), kulturowe (strategie konstruowania przekazu) i językowe (zasady konstruowania sloganu reklamowego). Zdaniem Sawickiej współczesna reklama opiera się na konotacjach kulturowych jednego tylko wyrażenia: człowiek nowoczesny, oznaczającego osobę postępową, idącą z duchem czasu, niezacofaną, postępującą zgodnie z preferowanymi kanonami. Charakteryzuje się estetycznym wyglądem, jest elegancka i zadbana, świetnie zorganizowana, dba o zdrowie własne i rodziny (osobowość), jest otwarta na to, co nowe, ale szanuje też tradycje (postępowanie), potrzebuje luksusu, wygodnego życia oraz poczucia bezpieczeństwa (pragnienia).

W badanych przeze mnie tekstach zamieszczanych na internetowych stronach gabinetów stomatologicznych znajdujemy realizację tego założenia przez odwołania do następujących wartości:

7 Definicję wartości przyjmuję za Elżbietą Laskowską: „Wartość jest cechą $w$ skali dobry-zły przypisywaną przedmiotowi (obiektowi) przez osobę (subiekta) ze względu na pewne kryterium" [Laskowska 1992: 13]. 
- pragmatycznych pozaekonomicznych (wskazujących na skuteczność, kompleksowość działań) ${ }^{8}$ :

Przytulne wnętrze poczekalni i gabinetów, przyjazny zespół oraz komputerowe znieczulenie TheWandTM sprawią, że wizyta przebiegnie sprawnie i komfortowo. [quldent.pl, dostęp 19.08.2013]

Zapraszamy na szybkie i bezpieczne wybielanie zębów! [dentalmedicenter.eu, dostęp 08.01.2014]

- ekonomicznych (niska cena, rabaty i promocje, dodatki, bonusy, upominki):

Naszym priorytetem jest utrzymanie cen na właściwym poziomie. [machniak.pl, dostęp 08.01.2014]

(...) rodzice będą mogli napić się kawy czekając na swoje pociechy. [dentista-olsztyn.pl, dostęp 08.01.2014]

Zniżka dla studentów. Wiemy, że studencka kieszeń nigdy nie jest dość pełna, dlatego u nas otrzymacie $20 \%$ zniżki na leczenie! [medident.pl, dostęp 08.01.2014]

- hedonistycznych (umniejszanie stereotypowych niedogodności związanych z leczeniem stomatologicznym: bezbolesność, poczucie komfortu):

Pomagamy naszym Pacjentom odzyskać piękny i zdrowy uśmiech bez stresu i bólu i w komfortowych warunkach. [dantalcare.biz.pl, dostęp 08.01.2014]

Nowoczesne i przestronne wnętrza oraz doskonale wyposażone gabinety gwarantują nie tylko najwyższą jakość zabiegów, ale również poczucie relaksu i odprężenia w czasie pobytu $w$ naszej klinice. [stomatologia25.pl, dostęp 08.01.2014]

(...) czekamy na Ciebie $w$ komfortowym i sprzyjającym relaksowi otoczeniu. [machniak.pl, dostęp 08.01.2014]

8 Wszystkie przykłady przytoczono w ich oryginalnej postaci, mogą w nich zatem występować błędy i usterki językowe. 
- wartości odczuć(samoakceptacja, szczęście, wyjątkowość):

U nas doskonale rozumiemy jak ważną podstawą sukcesu staje się dopracowany wizerunek, dlatego oferujemy najkorzystniejsze dla naszych Pacjentów metody wybielania zębów. [ortolan.pl, dostęp 03.11.2013]

Nie od dziś wiadomo, jakie znaczenie ma uśmiech $w$ naszym życiu. Uśmiechając się, zjednujemy sobie ludzi, sprawiamy wrażenie miłych, otwartych i serdecznych. Śmiech wnosi w nasze życie szczęście, którym zarażamy wszystkich wokół. [ortopasja.pl, dostęp 08.01.2014]

Wraz z nami odzyskasz pewność siebie i doskonałe samopoczucie. [quldent.pl, dostęp 19.08.2013]

- wartości witalnych (życie, zdrowie, młodość, sprawność fizyczna):

Dzięki implantologii i stomatologii estetycznej dentysta może odmienić twoje życie. [quldent.pl, dostęp 19.08.2013] Młoda, entuzjastyczna kadra. [usmiechnij-sie.pl, dostęp 08.01.2014]

(...) poprawiamy zarówno estetykę, funkcję żucia, jak i komfort życia pacjenta. [medis-med.pl, dostęp 03.05.2013]

- społecznych (popularność, uprzejmość, kontaktowość, moda):

(...) zajmujemy się sztuką tworzenia wizerunku, wyrażania samego siebie, pogodnego kontaktu z drugim człowiekiem. [morzeusmiechu.pl, dostęp 08.01.2014]

Dbając o swoje zdrowie oraz wygląd stajemy się coraz bardziej atrakcyjni, co przyczynia się do podniesienia własnej samooceny i pewności siebie. Z osobami takimi inni chętnie podejmują wszelkie działania w życiu towarzyskim jak i biznesie. [denta-med.com.pl, dostęp 08.01.2014]

Wiemy jak nawiązać kontakt z Twoim dzieckiem. [slonecznygabinet.pl, dostęp 08.01.2014] 
- perfekcjonistycznych (precyzja, gwarancja):

Podstawową wartością obowiązującą w naszej praktyce, jest rzetelne poinformowanie Pacjenta o stanie jego uzębienia [rozdent.pl, dostęp 08.01.2014]

Precyzję osiągamy dzięki zaawansowanej diagnostyce [moj-dentysta.pl, dostęp 08.01.2014]

Wszystkie implanty stosowane $w$ naszych gabinetach objęte są dożywotnią gwarancją. [stomatologia-cichon.pl, dostęp 08.01.2014]

- poznawczych (doświadczenie i wiedza):

Posiadam ponad dwudziestoletnie doświadczenie zawodowe. [cezardent.pl, dostęp 09.01.2014]

Jestem członkiem założycielem Polskiego Towarzystwa Endodontycznego. [cezardent.pl, dostęp 09.01.2014]

W naszym gabinecie stomatologicznym pracują doświadczeni i profesjonalnie przygotowani stomatolodzy różnych specjalizacji. [clinident.pl, dostęp 08.01.2014]

- estetycznych (piękno, atrakcyjność fizyczna):

Tzw. hollywoodzki uśmiech to marzenie wielu osób. [evadent.pl, dostęp 03.11.2013]

Piękny uśmiech jest wizytówką sukcesu i zdrowia. [arsmeddent.com.pl, dostęp 08.01.2014]

Piękny harmonijny uśmiech jest przyciągającym wzrok sygnałem zdrowia, atrakcyjności i pewności siebie. [stomatolog-marki.pl, dostęp 08.01.2014]

- etycznych (szacunek, odpowiedzialność):

Nie byłoby nas bez Państwa zaufania. [denmed.torun.pl, dostęp 08.01.2014]

Naszych pacjentów staramy się otoczyć jak najlepszą opieką stomatologiczną. [dental.com.pl, dostęp 08.01.2014] 
U nas każdy traktowany jest indywidualnie i z szacunkiem, i życzliwością. [dentalcare.biz.pl, dostęp 08.01.2014]

Zaprezentowane fragmenty tekstów z internetowych stron gabinetów stomatologicznych wskazują, że reklama poprzez wykorzystywanie leksyki wartościującej stara się tworzyć nowy świat, lepszą i wymarzoną rzeczywistość, stając się zwierciadłem stereotypów utrwalonych w zbiorowej świadomości. Przedstawione powyżej przykłady mają - niejako hipnotyzując odbiorcę - przekonać go do określonego stanowiska lub nakłonić do pożądanych zachowań. W analizowanych tekstach uobecnia się motyw człowieka nowoczesnego - takiego, który chce wyglądać estetycznie, ceni perfekcyjne działanie, jest otwarty na nowe, ale też przejawia szacunek dla tradycji i potrzebuje luksusu, aby pieczołowicie budować poczucie własnej wartości. W tym celu reklama „absorbuje z rzeczywistości społeczno-kulturowej różnorodność form i treści, aranżuje je odpowiednio (ideologicznie) w swoim przekazie tak, by odbiorca przenosił bogate znaczenia symbolu na marketingowy fetysz XX wieku - markowy produkt" [Duda 2010: 93]. Reklamowana usługa ostatecznie zostaje zastąpiona symbolem, a raczej wyobrażeniem. Mimo że między symbolem (lub wyobrażeniem) a produktem (usługą) brak rzeczywistego związku, odbiorca ma przekonanie, że oba mają takie samo znaczenie. Tony Schwartz, odwołując się do pojęcia rezonansu, tłumaczy, że przekaz musi zadźwięczeć, poruszyć odpowiedni struny doświadczenia, myśli i emocji odbiorcy. O sensie komunikatu stanowi maksymalne dopasowanie do schematów poznawczych i całej konstrukcji emocjonalnej odbiorcy [Schwartz 1974: 25 - za: Duda 2010: 94]. Odczytanie przekazu odbywa się bowiem zawsze w określonej sytuacji społecznej i kulturowej - odbiorca ma własny system ocen, dysponuje własnym układem odniesienia. Przekaz reklamowy zaś odwołuje się do tęsknot tegoż odbiorcy za określonym stylem życia ${ }^{9}$ (lifestyle

9 „Reklama [...] oferuje mu [kupującemu] wizerunek jego samego jako kogoś, kto dzięki produktowi bądź okazji, które próbuje ona sprzedać, może stać się osobą godną zazdrości [...] reklama mówi o stosunkach społecznych, nie o rze- 
advertising), będącym realizacją jakiegoś wariantu wybranego $\mathrm{z}$ większego zasobu dostępnego w kulturze ${ }^{10}$. Przyjęcie określonego stylu życia daje poczucie bezpieczeństwa ${ }^{11}$.

Wpływ mediów na ludzkie zachowanie, postawy i styl życia jest znaczny, logika medialna coraz częściej wpisuje się w codzienną rzeczywistość, narzucając swoją obrazowość oraz rytmiczną sekwencyjność ${ }^{12}$. Reklama - będąc dyskursem o strukture otwartej [Bogunia-Borowska 2004: 64] - angażuje odbiorcę, ustala trendy i kierunki zachodzących zmian. Jawi się też jako proces informowania zaprogramowanego i ukierunkowanego na określony konsumpcyjny cel. Kreuje wyidealizowany świat człowieka nowoczesnego, który dzięki swej otwartości na nowe doświadczenia stał się też swoistym wzorcem kulturowym. Język mitu nadbudowuje sensy nad systemem lingwistycznym, a obrazy reklamowe sprzedają produkty (lub raczej ich wizje) przez to, że łączą je z wartościami.

Można zatem stwierdzić, że reklama modeluje wiele aspektów ludzkiego życia, stając się medialną encyklopedią współczesności [Bogunia-Borowska 2004: 47]: prezentuje świat społeczny w wielu kontekstach, dostarcza nam obrazów sugerujących, jak chcielibyśmy żyć, tworzy wizje w naszych umysłach, a dyskurs ten opiera się na głęboko osadzonych w ludzkiej podświadomości symbolach szczęścia, zdrowia i sukcesu. Mityczny sposób myślenia jest uniwersalny i ponadczasowy, ostatecznie kupuje się obraz stworzony przez reklamę, obraz lepszego świata tkwiący $w$ nas samych.

Reklama jako zjawisko lingwistyczne ma wielu przeciwników, należy jednak zwrócić też uwagę na twórczy charakter jej języka13. Godne uwagi jest tu stanowisko Ireny Kamińskiej-Szmaj, które warto przytoczyć na zakończenie artykułu:

czach. Obiecuje nie tyle przyjemności, ile szczęście. Takie, które jest oceniane z zewnątrz, przez innych. Szczęście bycia kimś godnym zazdrości to blichtr" [Berger 2005: 480-481].

10 Zob. Czerwiński 1976: 63.

11 Zob. Giddens 2001: 114.

12 Zob. Welsch 2005: 471.

13 Jan Miodek zwraca uwagę, że do skrzydlatych słów w Polsce, między innymi z literatury pięknej, mitologii, dołączyły slogany reklamowe - zob. Miodek 2003: 75. 
Reklama w znaczeniu komunikacji społecznej [...] uczy nas pozytywnie reagować na zjawiska otaczającej rzeczywistości, wzbudzać $w$ sobie pozytywne emocje. Przede wszystkim reklama wzbogaca nasze słownictwo o barwie uczuciowej dodatniej. Język polski ma bogatą leksykę o nacechowaniu negatywnym (w polszczyźnie łatwiej kogoś obrazić niż pochwalić), co wiąże się zapewne z naszą historią i dawnymi stosunkami politycznymi, a dokładniej z kształtowaniem się języka historii i polityki opartych na perswazji - nazwijmy ją - negatywnej. Być może reklamowy sposób postrzegania świata przyczyni się do zmniejszenia dysproporcji między słownictwem obrażającym, negatywnie wartościującym a słownictwem oceniającym pozytywnie. [Kamińska-Szmaj 2003: 79]

\section{Bibliografia}

Baranowska A. [1999], Prawda a kłamstwo w reklamie, [w:] Język - biznes - media. Materiały konferencyjne, Arabski J. (red.), Wyższa Szkoła Zarządzania Marketingowego i Języków Obcych, Katowice.

Benedikt A. [2005], Reklama jako proces komunikacji, Astrum, Wrocław.

Berger J. [2005], Obrazy reklamowe, [w:] Nowe media w komunikacji społecznej $X X$ wieku, Hopfinger M. (red.), Oficyna Naukowa, Warszawa.

Bogunia-Borowska M. [2004], Reklama jako tworzenie rzeczywistości społecznej, Wydawnictwo Uniwersytetu Jagiellońskiego, Kraków.

Bralczyk J. [1996], Język na sprzedaż, Businessman, Warszawa.

Czerwiński M. [1976], Pojęcie stylu życia i jego implikacje. Styl życia. Koncepcje, propozycje, Sicińska A. (red.), Wydawnictwo Naukowe PWN, Warszawa.

Danielewiczowa M. [1993], O pojęciu konotacji wartościującej, [w:] Studia semantyczne, Grzegorczykowa R., Zaron Z. (red.), Wydawnictwo Uniwersytetu Warszawskiego, Warszawa.

Doliński D. [2001], Psychologia reklamy, wyd. II, Aida, Wrocław.

Doliński D. [2003], Psychologiczne mechanizmy reklamy, Gdańskie Wydawnictwo Psychologiczne, Gdańsk.

Duda A [2010], Język mitu w reklamie, Wydawnictwo KUL, Lublin.

Giddens A. [2001], Nowoczesność i tożsamość. "Ja" i społeczeństwo w epoce późnej nowoczesności, tłum. Szulżycka A., Wydawnictwo Naukowe PWN, Warszawa. 
Grochala B. [2008], Hiperbolizacja jako narzędzie marketingowe, [w:] Język $w$ marketingu, Michalewski K. (red.), Wydawnictwo Uniwersytetu Łódzkiego, Łódź.

Grzegorczykowa R. [1991], Problem funkcji języka i tekstu w świetle teorii aktów mowy, "Język a Kultura", t. 4: Funkcje języka i wypowiedzi, Bartmiński J., Grzegorczykowa R. (red.), „Wiedza o Kulturze”, Wrocław.

Grzegorczykowa R. [1995], Jak rozumieć kreatywny charakter języka, [w:] Kreowanie świata $w$ tekstach, Lewicki A. M., Tokarski R. (red.), Wydawnictwo UMCS, Lublin.

Językowy obraz świata [1999], Bartmiński J. (red.), wyd. II popr., Wydawnictwo UMCS, Lublin.

Kacprzak A. [2008], Sztuka perswazji zaczyna się od słowa, [w:] Język w marketingu, Michalewski K. (red.), Wydawnictwo Uniwersytetu tódzkiego, Łódź.

Kamińska-Szmaj I. [2003], Perswazja w tekstach reklamowych - spojrzenie językoznawcy, [w:] Język perswazji publicznej, Mosiołek-Kłosińska K., Zgółka T. (red.), Wydawnictwo Poznańskie, Poznań.

Kreowanie światów w języku mediów [2007], Nowak P., Tokarski R. (red.), Wydawnictwo UMCS, Lublin.

Laskowska E. [1992], Wartościowanie w języku potocznym, Wyższa Szkoła Pedagogiczna, Bydgoszcz.

Laskowska E. [2008], Wartościowanie jako środek perswazji, [w:] Język, społeczeństwo, wartości, Laskowska E., Benenowska I., Jaracz M. (red.), Bydgoskie Towarzystwo Naukowe, Bydgoszcz.

Leśniewska A. [2006], Reklama internetowa: stwórz klientowi jego własny świat, Wydawnictwo Helion, Gliwice.

Lewiński P. H. [1999], Retoryka reklamy, Wydawnictwo Uniwersytetu Wrocławskiego, Wrocław.

Lewiński P. H. [2000], Obraz świata w reklamie, „Język a Kultura”, t. 13: Językowy obraz świata i kultura, Dąbrowska A., Anusiewicz J. (red.), Wydawnictwo Uniwersytetu Wrocławskiego, Wrocław.

Lobka A. [2001], Kreowanie wizerunku własnego w mediach, [w:] Nowe media - nowe w mediach, Borkowski I., Woźny A. (red.), Wydawnictwo Uniwersytetu Wrocławskiego, Wrocław.

Manipulacja w języku [2004], Krzyżanowski P., Nowak P. (red.), Wydawnictwo UMCS, Lublin.

Miodek J. [2003], Perswazja w tekstach reklamowych - wprowadzenie do dyskusji, [w:] Język perswazji publicznej, Mosiołek-Kłosińska K., Zgółka T. (red.), Wydawnictwo Poznańskie, Poznań.

Molek K. [2001], Wartościowanie jako językowy środek perswazyjny $w$ tekstach reklamowych, [w:] Język $w$ komunikacji, Habrajska G. (red.), t. 3, Wydawnictwo Wyższej Szkoły Humanistyczno-Ekonomicznej, Łódź. 
Reeves B., Nass C. [2000], Media i ludzie, tłum. Szczerkowska H., Państwowy Instytut Wydawniczy, Warszawa.

Sawicka G. [2007], Dynamika reklamy jako stylu komunikacyjnego, [w:] Język polski XXI wieku: analizy, oceny, perspektywy, Szpila G. (red.), Tertium, Kraków.

Schwartz T. [1974], The responsive Chord, WN YC, New York.

Szczęsna E. [2003], Poetyka reklamy, Wydawnictwo Naukowe PWN, Warszawa.

Świątek J. [2007], Obraz jako element struktury argumentacyjnej - kilka uwag na temat funkcji warstwy wizualnej przekazów reklamowych, [w:] Język polski XXI wieku: analizy, oceny, perspektywy, Szpila G. (red.), Tertium, Kraków.

Tokarski R. [1995], Mechanizmy perswazyjne w reklamie, „Aida Media” 1995, nr 10.

Tokarski R. [2001], Słownictwo jako interpretacja świata, [w:] Współczesny język polski, Bartmiński J. (red.), Wydawnictwo UMSC, Lublin.

Wartości w języku i tekście [1991], Puzynina J., Anusiewicz J. (red.), Język a Kultura, t. 3, „Wiedza o Kulturze”, Wrocław.

Welsch W. [2005], Sztuczne raje? Rozważania o świecie mediów elektronicznych i o innych światach, [w:] Nowe media w komunikacji społecznej XX wieku, Hopfinger M. (red.), Oficyna Naukowa, Warszawa.

Zagadnienia leksykalne i aksjologiczne [1991], Puzynina J., Bartmiński J. (red.), Język a Kultura, t. 2, „Wiedza o Kulturze”, Wrocław.

Zimny R. [2008], Kreowanie obrazów świata w tekstach reklamowych, Wydawnictwo Trio, Warszawa. 